資 料

\title{
電子計算機による内田クレペリン検查作業曲線の処理 ${ }^{1}$
}

一大阪大学吉田光 雄 ${ }^{2}-$

I

近年, 目覚ましく発展しつつある電子計算機は, 各方 面でのデータ処理に活躍し, 数值計算のみならず, 非数 徝的なものの取り扱いに和いても气の偉力を発揮してい る。すなわち, いくつかの論理演算機構が組み入れられ ていることから, 例えば機械翻訳（和田，1962）, パタン 認識（坂井, 1962), 作曲 (大譛, 1963) 等の情報処理も 行なわれている。理学の分野でも戸田・寺岡 (1965) も述べるごとく，パーソナリティシミュレーション (Tomkins \& Messick, 1963) 他各種のシミュレーショ ン (Coleman, 1961; Hovland, 1960; Green, 1961 ; Laughery \& Gregg，1962）に電子計算機が使用されて いるが，本稿では，内田クンペリンテスト結果の処理・ 判定を行なら方法について報告するるのである.

内田クレペリンテストは, 結果が各分作業量という形 で数量的に表示され，必要に応じて数量的分析が施され 客観的解釈がなされる反面, 熟練者の経験から曲線の様 相が評価され，人格特性と関連づけて解釈されるという 值観的な面をも含んでいる，かくのごとき性格テストは 電子計算機のシステムに載せるのには最適と思われる. すなわち,プロフィールから主観的に諸徴候の存在特よ び程度が推量されるにすぎなかったるのに数量的基盤を 与光ることができること, 更に曲線のプロフィール認知 を計算機に行なわせることによって判定者の個人差から 脱却できること，等である。

そこで, 内田のテキスト（内田，1951；内田，1957； 日本精神技術研究所, 1955) から, 曲線々同様に各分作 業量が明示されているものを抜き出し(総計 80 例に達 几た）それに与えられた判定をもとに曲線の定型性を判

\footnotetext{
1 Data processing of the work curve of UchidaKraepelin Test by electronic computer.

2 Mitsuo Yoshida (Osaka University)

電子計算機使用に関して御好意いただいた大阪大学計 算センターに感謝いたします。

325 分法テストの場合には 25 個。

$4 X$ は前期作業量, $Y$ は後期作業量を表わするのとす 3.
}

定するプログラムを作成した。使用機種は大阪大学所有 の日本電気 (株) 製 NEAC-2206. PTR (Photo Tape Reader)よりデータを読込み, OUT PUTはHTP (High Speed Tape Punchet) より打ら出した後, オフライン 処理でプリントする。プログラムは機械語で書かれ約 1,700 語, データの格納をも含めて約 2,000 語のメモり 一を専有する。

\section{II}

IN PUT は被験者番号 3 枌, 氏名頭文字 2 文字, 特よ び各分作業量を 2 桁づつ 30 個 $^{3}$, 最後にエンドマーク Y. OUT PUT 例は Fig. 1 のごときものであるが記号 の意味は次の通りである。

(1) 作業量平均値一一前期作業量平均値 $M X$, 後期 作業量平均値 $M Y^{4}$.

（2）平均値汶対する各分作業量指数值一一前期作業 量の前期平均に対する指数値 $X / M X$, 後期作業量の前期 平均値に対する指数值 $Y \mid M X$, 後期作業量の後期平均值 に対する指数值 $Y / M Y$ を小数点以下を四捨五入して 3 桁打ち出す.

（3）作業量に対する量級の判定一一平均值を用いて 量級段階を前後期別飞判定し， $P X, P Y$ として打ち出 す. テキストの基準（内田, 1957, p. 9) 飞従い, $M X$ $\geqq 55$ のとき $P X=@, 40 \leqq M X<55$ のとき $P X=A$ を プリント, 以下同様.

（4）休鄎效果率— $R=M Y \mid M X \%$ を算出, 後の 処理に際して $105 \leqq R \leqq 130$ の場合を休覟効果女りと見 なす。

（5） NORMAL INDEX一一相馬（1949）は25 分法 テストル扮いて, 後期 10 分の作業量から常態指数値と して相関係数を算出する方法を報告しているが，現在で は专まり使用されていないようである。しかしこれは指 数法そのものの欠陥ではなく(柏木, 1962), プロフィー ルを数量的に取り扱ら一方法として, 規準曲線との相関 係数を算出して，NORMAL INDEX とした，規準曲線 の各分作業量を $a_{i}$ とすれば

$$
N I=\frac{\sum\left(a_{i}-\bar{a}_{i}\right)\left(x_{i}-\bar{x}\right)}{\sqrt{\sum\left(a_{i}-\bar{a}\right)^{2} \cdot \sum\left(x_{i}-\bar{x}\right)^{2}}}
$$


で算出される、 $a_{i}$ にいかなる数值を採用するかによっ てNI の值は異なり, かつ, 期待曲線のプロフィールは 作業量段階に応じて変わることが報告されているが（柏 木, 1962, 1964), 先ず予備テストの段階で平均曲線（内 田, 1957, p. 29) 起投入すると, 同曲線自身が平坦にす ぎて曲線の特徵を十分に表現し得ない，そこで同曲線の 特徵を強調した数值を採用し（具体的には同曲線の指数 值を修正したもの), 曲線 16 類型と $N I$ との相関を求 めると, $r=0.5815$ から $r=0.6332$ に向上した. $N I$ 值 の分布は Fig. 2 に示す通りである. 図にも明らかなご とく, NI 值単独では曲線の定型性を弁別し得ないが, 重要なパラメターとして後にとり上げられる。

（6）変異数一一作前量のちらばりを示す指標として $V=\sqrt{\sum(x-\bar{x})^{2}} / \bar{x}$

を定義する、Vのみでは定型性との一意的関連は薄かっ た。

（7）初頭努力, 終末努力の有無の判定一一テキスト の基準（内田，1957， p. 58）を参考にしつつ, 以下のご とき判定基準を定める。計算に際してはいずれも指数值 $(X / M X, Y / M X)$ を用いるが，先ず初頭努力として

$$
\begin{aligned}
& \text { (i) } \quad 110 \leqq X_{1} \leqq 125 \\
& \text { (ii) } 8 \leqq X_{1}-X_{2} \leqq 12
\end{aligned}
$$

の基準を定め, (i ) ○（ii）のとき，初頭努力出りと見 なして $S X=1$, その他の場合は初頭努力なしとして $S X=0$ をプリントする，後期初頭努力についても同様 V

$$
\text { (i) } 107 \leqq Y_{1} \leqq 120
$$

(ii) $7 \leqq Y_{1}-Y_{2} \leqq 11$

で (i ) ク (ii) のとき $S Y=1$, その他では $S Y=0$ で ある、終末努力は前期のみについて算出する。すなわ ら,

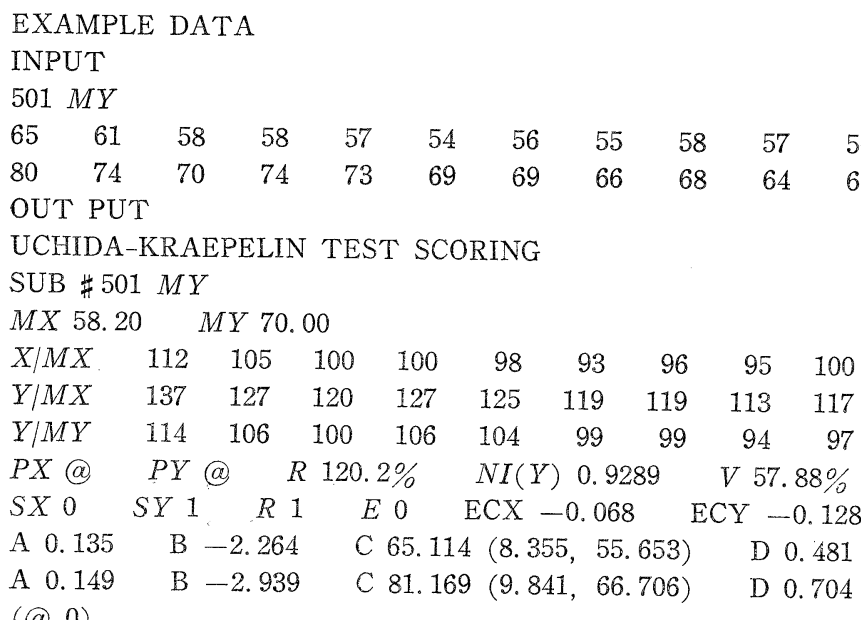

(i) $X_{15}>X_{14}$

(ii) $205 \leqq X_{14}+X_{15} \leqq 225$

で, (i ) $\cap$ (ii) のとき $E=1$, その他のとき $E=0$ を プリントする。 これらの $S X, S Y, E$ は後に曲線の定 型性判定の際のパラメターとなるが，（i ），(ii）の基準 を如何に決めるかによって結果は異なる. 最適の基準が 多数のデータから再検討されねばならない。

（8）興奮——興奮傾向は尻上がり（正の興奮）, 屑 下がり (負の興奮) の形で捕吕られよう。これを数量的 には

$$
\begin{aligned}
E C=\sum\left(x_{i}-x_{i-1}\right) / \bar{x} & \\
& i=2,3,4, \cdots \cdots, 15
\end{aligned}
$$

として前後期別に捕光た。

（9）最小自乘法による 2 次曲線回帰一一柏木(1962) は曲線を一種の振動過程として捕え, 指数関係をあては めているが，曲線は単調ではなく変域を変劣ねばならな い, そこで本稿では初頭努力, 中だるみ, 終末努力を単 一の式で表現しうるものとして，2次関数をあてはめる ことを試みた。すなおち, 特定の被験者について $t$ 分目 の作業量を $x_{t}$, その推定值を $\hat{x}_{t}$ とすると,

$$
\hat{x}_{t}=a t^{2}+b t+c
$$

なる式を与え, 最小自乗法にて係数 $a, b, c$ を被験者毎, 前後期別に算出した。最小自乗法では

$$
S=\sum d^{2}=\sum_{t=1}^{15}\left(x_{t}-\left(a t^{2}+b t+c\right)\right)^{2}=\min
$$

にすれば良いから，

$$
\frac{\partial s}{\partial a}=\frac{\partial s}{\partial b}=\frac{\partial s}{\partial c}=0
$$

を解いて次式を得る。すなわら,

$$
\left(\begin{array}{ccc}
\sum t^{4}, & \sum t^{3}, & \sum t^{2} \\
\sum t^{3}, & \sum t^{2}, & \sum t \\
\sum t^{2}, & \sum t, & n
\end{array}\right)\left(\begin{array}{l}
a \\
b \\
c
\end{array}\right)\left(\begin{array}{c}
\sum t^{2} x \\
\sum t x \\
\sum x
\end{array}\right)
$$

FIG. 1 An example of IN PUT and OUT PUT of computer. 
各被験者, 前後期別に（10）式を解き係数を算出し, 2 次関数の頂点 $(t, x)$ 拉よびあてはめの良さを表わす

$$
D=\sum d^{2} / \bar{x}
$$

を求めプリントする， $D$ 值の分布は Fig. 4 である. 勾 配を示す $a$ の大小, 対称軸 $-b / 2 a$ が 1 分から 15 分の 間に存するか否か，更に $D$ 值の大きさ等が曲線の解釈に 際して情報を提供する。例觉ば，Fig. 3-1は@の定型 であり, 勾配, 対称軸ともに模範的様相を呈し，2 次関 数のあてはめも非常に良い $(D<1.0)$. Fig. 3-2 は非定 型 $f(A)$ の例で, 後期曲線の勾配が負となること, $D$ 值 が大きく岕てはめが良くないことの例で岁る。更に，

Fig. 3-3 㦏常型で勾配, 対称軸, $D$ 值ともに正常曲線 とは程遠い，この曲線の場合， $N I=0.2120, V=179.04$ \%の 2 つからも弁別は容易である。

（10）曲線の定型性の判定一一最後汇計算機は曲線の 定型性を判定して打ち出すが，上述の各パラメターはい ずれも単独では，定型性を区別し得ない，Fig. 2 亿見る ごとく, NI では 0.7 を境界に準定型以上，準々定型以 下を2 分しても，それ以上の分類は不可能のよ5である し，また Fig. 4 に見るごとく $D$ 值を用いても，0.1 を もって準定型以上，準々定型以下の分類しか期待できな い. 従って定型性の判定で怔多くの数值を相互関連さ せつつ分類せざるを得ず, Fig. 5 に示すごとく論理判断 の手順を計算機に記憶させそれに従い各個人の曲線の判

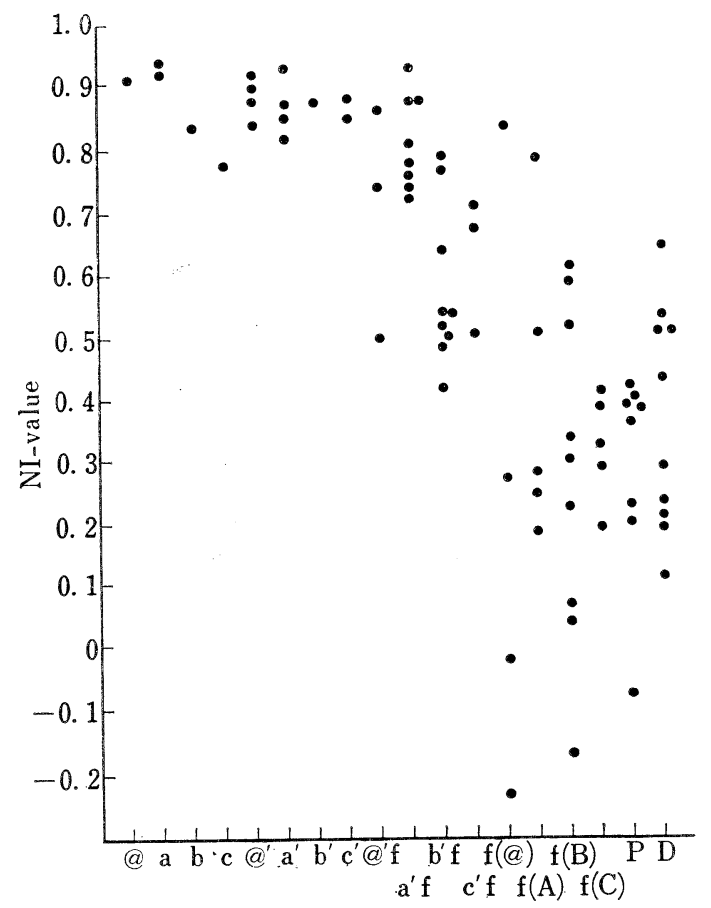

FIG. 2 Scatter diagram of $N I$.
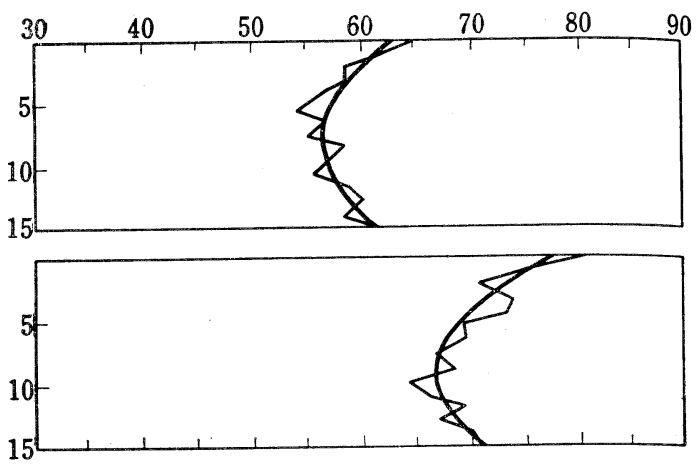

FIG. 3-1 @

$a=0.14 b=-2.26 c=65.11(8.36,55.65) \quad D=0.48$ $a=0.15 b=-2.94 c=81.17(9.84,66.71) \quad D=0.70$
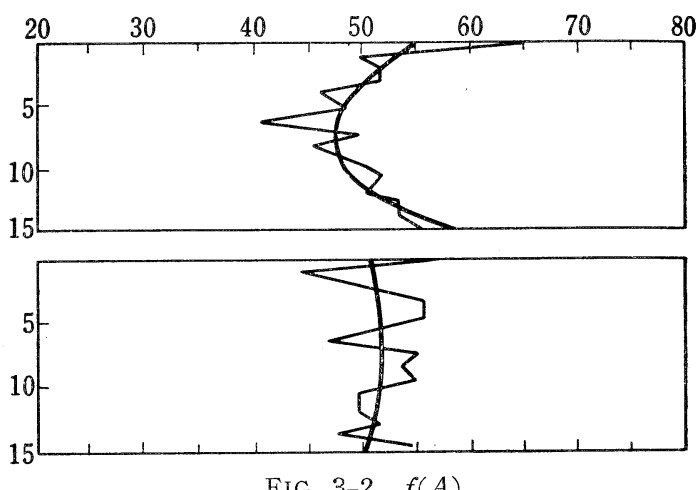

$a=0.22 b=-3.63 c=60.80(8.08,46.14) \quad D=3.59$ $a=-0.02 \quad b=0.31 \quad c=50.78(6.67,51.80) \quad D=3.82$
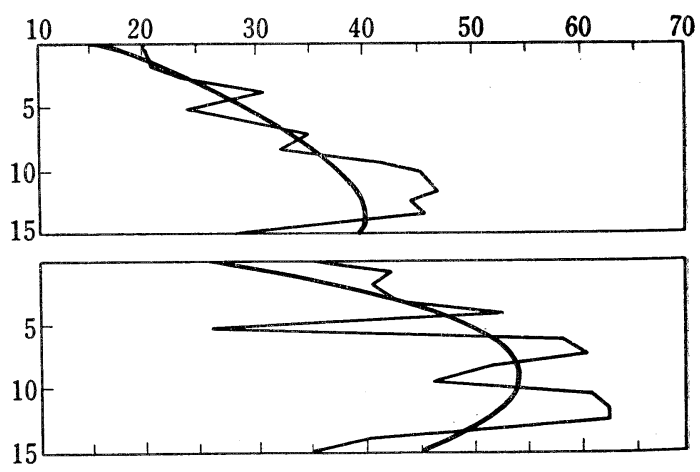

FIG. 3-3 $f_{p}$ $a=-0.18 \quad b=4.93 \quad c=8.31(13.33,41.17) \quad D=11.04$ $a=-0.30 b=5.66 \quad c=27.58(9.33,54.00) \quad D=26.15$

FIG. 3 Three examples of curve fltting $(\hat{x}=$ $\left.a t^{2}+b t+c\right)$ to the work curve of U-K test by least square method. Two numerics in ( ) denote vertex of parabola and $D$-value goodness of estimation. 
定を試みた。

ここで使用される数值は, 先ず作業量平均値, 次いで 主に $N I, D$, そ乙て部分的飞 $V$, 対称軸 $G$, 休馝効果

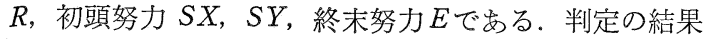
は OUT PUT の最後として（）内に打ち出す。ただ しプリントは, 定型 0 , 準定型 1 , 準々定型 2 , 非定型 3 と記号化し, $f_{p}, p$ は $P, d, d_{p}$ は $D$ を量級符号の次 に付す.Fig. 6 はテキストに判定された符号と、 コンピ ニーターの判定した符号との関連である。 80 例中 23 例 （5ち6 例は量級の不一致）の不一致が見られ, 両者の 相関は $r=0.8942$ であった.

\section{III}

プログラミングに際して, データが 80 例しか入手で きなかったために，判定の結果にもずれが多い，特に定 型, 準定型のめたりのデータが少なく予測も不十分であ った. Fig. 5 のフローチャートもいわば簡単すぎるもの であり, 熟練者の推理過程をかくのごとき簡単な図式で 表現できるとは考光られず, 更に複雑な条件設定, 分枝 を与光ねばならないであろう。本稿はその可能性への試 みである。また，一応の基準を定め数值を算出したが， その妥当性についてはいずれも未検討である。例完ば,

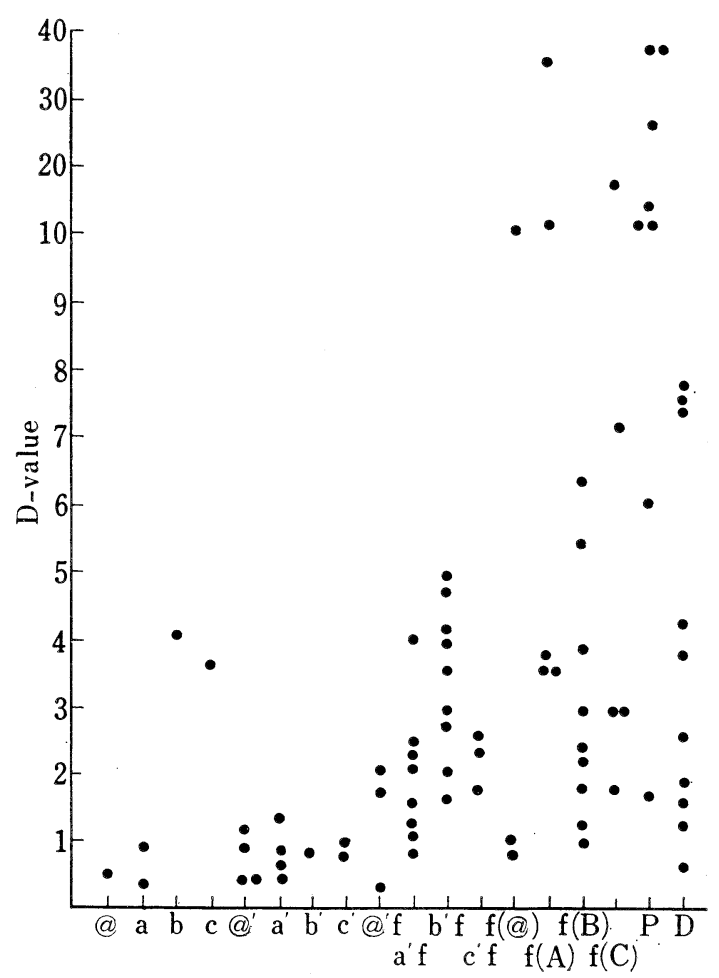

FIG. 4 Scatter diagram of $D$-value (only pre-rest period).
$N I$ に和惊る $a_{i}$, 初頭, 終末努力の判定基準等, 更に末 た，今回取り上げられなかった曲線の部分的特徴，例党 ば, 範囲, 陥没, 突出, 諨答等の数量的把握も不可欠で

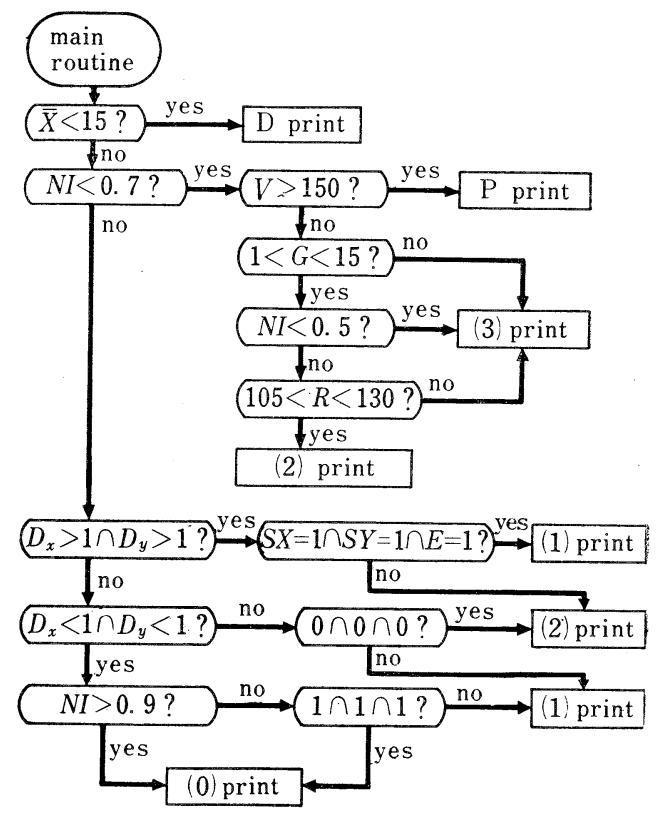

FIG. 5 Flow chart of the decision of the normality.

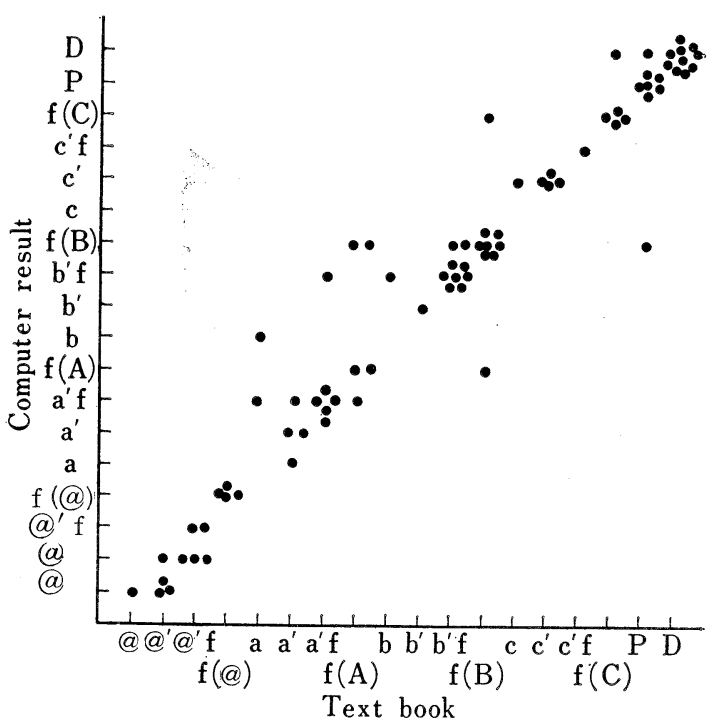

FIG. 6 Correlation between the decision of professionals (in the text book) and that of computer. High correlation is obtained, namely $\boldsymbol{r}=$ 0.8942 . 
㐫ろう。こうした諸点の分析は今後の課題としたい。

社員選拔, 適性配置の資料として本テストが広く利用 され，わが国にも大企業の殆んぞには電子計算機が導入 されている今日，テスト結果をEDPS 飞載せて解秎する ことも可能であり，その実用性も大きいと思われる．

最後に処理時間について記すならば，原データ読込み から HTP 打出しまで, オンライン処理で約 15 秒/人で めった. しかし実際にはデータのパンチ, 結果のコピー にかなりの時間を要する。

\section{引用文献}

Coleman, J.S. 1961 Analysis of social structures and simulation of social process with electronic computer. Educ. psychol.Measmt., 21, 203-218.

Green, B. F. 1961 Computer models of cognitive process. Psychometrika, 26, 85-91.

Horst, P., Dvorak, A., \& Wright, C. 1961 Computer application of psychological problems. Educ. psychol. Measmt., 21, 699-719.

Hovland, C. I. 1960 Cumputer simulation of thinking. Amer. Psychologist. 15, 687-694.

柏木繁男 1962 内田クレペリン検查の作業曲線につい て 心研, 33, 98-100.
柏木繁男 1964 内田クレペリン検査の信頼性と妥当性 の客観的手法による検討 心研， 35. 93-95.

Laughery, K.R., \& Gregg, L. W. 1962 Simulation of human problem-solving behavior. Psychometrika, 27, 265-282.

日本精神技術研究所編 1955 内田クレペリン検查法早 わかり 日本精神技術研究所.

大梘説乎 1963 計算機の経験とよる作曲の試及 情報 処理, 4, 16-24.

坂井利之 1962 パタン認識 情報処理, 3, 189-196.

Seible, R. 1961 Computer solutions to some noncomputational psychological problems. Educ. psychol. Measmt., 21, 185-201.

相馬紀公 1949 内田クレペリン精神検査の数量的取扱 、日本精神技術研究所.

戸田正直・寺岡 隆 1965 数学的心理学概観 心研, 36, 76-93.

Tomkins, S. S., \& Messik, S. (Ed.) 1963 Computer simulation of personality. New York: John Wiley.

内田勇三郎 1951 内田クレペリン精神検査法手引 日 本精神技術研究所

内田勇三郎 1957 新適性検查法 日刊工業新聞社.

和田 弘 1962 機械翻訳 情報処理, 3, 144-154. 